\title{
The Rush to Execution: Successive Habeas Corpus Petitions in Capital Cases
}

\author{
John B. Morris, Jr.
}

On May 25, 1979, when John Spenkelink became the first person in recent times in the United States to be executed against his will, he still maintained a claim of ineffective assistance of counsel, a claim on which no court ever ruled. ${ }^{1}$ Three years later, when Charles Brooks became the next person to be involuntarily executed, he too had claims that were never fully reviewed by any court. ${ }^{2}$ Since then, many of the over forty people executed have had claims that were either ignored or summarily rejected by the federal courts. ${ }^{3}$

The constitutional claims not reached by the courts in these cases were raised in successive, or second, petitions for habeas corpus. The summary disposal of potentially valid constitutional claims raises questions about the integrity of the system used to impose the death penalty. While capital punishment can be attacked on a variety of moral, philosophical, and legal grounds, it is clear that in the current political and judicial climate the death penalty will withstand these attacks. ${ }^{4}$ Nevertheless, both opponents and proponents of capital punishment should object to executing men and women before their constitutional claims are adjudicated. ${ }^{5}$ The federal

1. Spinkellink [sic] v. Wainwright, No. 79-8215 (5th Cir. May 24, 1979) (order vacating stay of execution). Senior Circuit Judge Elbert Tuttle had, near midnight on May 22, granted a stay of execution based on new claims of ineffective assistance of appellate counsel. A three-judge panel of the Fifth Circuit vacated that stay, without issuing any ruling on the merits of the claim. John Spenkelink was executed the following morning.

The court specifically stated that they would explain their actions in a formal opinion. Id. No opinion, however, has ever been issued. See Clark, Spenkelink's Last Appeal, NATTON, Oct. 27, 1979, at 385, 403-04. The Florida courts had not previously ruled on the ineffectiveness of appellate counsel claim. See Spenkelink v. State, 372 So. 2d 927 (Fla. 1979) (per curiam); Spenkelink v. Wainwright, 372 So. $2 d 65$ (Fla. 1979) (per curiam).

2. Brooks v. Estelle, 702 F.2d 84 (5th Cir. 1983) (per curiam) (dismissing Brooks' appeal as moot four months after he was executed).

3. See, e.g., Antone v. Dugger, 465 U.S. 200 (1984) (per curiam); Stanley v. Kemp, 737 F.2d 921 (11th Cir. 1984) (per curiam); In re Shriner, 735 F.2d 1236 (11th Cir. 1984); Smith v. Kemp, 715 F.2d 1459 (11th Cir.), cert. denied, 464 U.S. 1003 (1983).

4. Currently, Justices Brennan and Marshall are the only members of the Court ready to strike down capital punishment. See Gregg v. Georgia, 428 U.S. 153, 227 (1976) (Brennan, J., dissenting); id. at 231 (Marshall, J., dissenting). The reenactment of capital sentencing provisions by over twothirds of the states' legislatures since most previous statutes were overturned as a result of Furman v. Georgia, 408 U.S. 238 (1972) (per curiam), suggests that the political process is not likely to abolish
capital punishment any time soon.

5. See Coleman v. Balkcom, 451 U.S. 949, 955 (1981) (Marshall, J., dissenting from denial of certiorari). 
courts' new approach to successive petitions creates the risk-indeed, over time, the certainty-that some valid claims will go unexamined. In the context of a death sentence, this risk is unacceptable.

After reviewing the history and the current state of the law of successive habeas corpus petitions, this Note analyzes the various types of successive claims and the different procedural situations in which they arise. The Note then proposes a new, two-pronged approach to successive petitions in capital cases. The proposal would remedy the sacrifice of constitutional justice caused by recent efforts to speed the imposition of the "ultimate sanction."

\section{Judicial Review of Successive Petitions}

\section{A. The Current Approach}

With John Spenkelink's execution, the Supreme Court signalled a new approach to the consideration of successive habeas corpus appeals, traditionally termed "abuse of the writ" cases. "The Court's new policy, only now becoming clear, is to deny second and third habeas petitions promptly and summarily, without reaching or carefully considering the substantive merits of the claims raised. Although it has never explicitly acknowledged this new approach, the Court's actions reflect a pronounced shift to a new rule governing successive habeas petitions.

Individual Justices of the Supreme Court have at times urged the Court to alter its approach to successive petitions. When he was still Assistant Attorney General, Justice Rehnquist unsuccessfully encouraged Congress to restrict the writ of habeas corpus. ${ }^{8}$ In 1983, Justice White wrote: "Except in unusual circumstances, successive writs [sh]ould be summarily denied." Justice White did, however, acknowledge that the case law of the Court and the proceedings of Congress "implicitly recognize the legiti-

6. Id.

7. Spenkelink v. Wainwright, 442 U.S. 906 (May 25, 1979) (denying stay of execution); Spenkelink v. Wainwright, 442 U.S. 901 (May 24, 1979) (same). In addition to being the first person involuntarily executed since the validation of the modern death penalty statutes in Gregg v. Georgia, 428 U.S. 153 (1976) (plurality opinion), Spenkelink was also the first capital defendant in the postGregg era to attempt to use a successive habeas corpus petition.

8. See Hearings on S. 895 Before the Subcomm. on Constitutional Rights of the Senate Comm. on the Judiciary, 92nd Cong., 1st Sess. 94, 102 (1971). Florida Governor Bob Graham has also lobbied Congress to restrict federal habeas corpus. Adler, Florida's Zealous Prosecutors: Death Specialists, AM. LAw., Sept. 1981, at 35, 36. Justice Rehnquist, through his opinions, and Governor Graham, through his state's Attorney General's office, are thus pressing positions that both unsuccessfully advocated before Congress.

9. Autry v. Estelle, 464 U.S. 1301, 1303 (White, Circuit Justice 1983) (issuing stay of execution pending decision in similar case). 
macy of successive petitions raising grounds that have not previously been presented and adjudicated."10

Without announcing the change, the Supreme Court has in fact begun to employ the approach contemplated by Justice White. Using brief per curiam opinions ${ }^{11}$ and summary dispositions, ${ }^{12}$ the Court quickly disposes of most capital habeas petitions. It is now clear that in practice if not in theory, the Supreme Court has adopted an implicit presumption against reaching the merits of issues raised in successive petitions. ${ }^{13}$

This new approach, increasingly followed by the lower federal courts, ${ }^{14}$ will have a far-reaching impact on all areas of criminal rights ${ }^{15}$ and will improperly limit the ability of capital defendants to raise valid constitutional claims. ${ }^{18}$ This approach runs counter to the history of habeas corpus and the intent of Congress in framing the federal habeas statutes.

\section{Id.}

11. E.g., Antone v. Dugger, 465 U.S. 200 (1984) (per curiam) (denying stay and certiorari); Woodard v. Hutchins, 464 U.S. 377 (1984) (per curiam) (vacating, less than six hours before scheduled execution, stay granted by circuit court); Maggio v. Williams, 464 U.S. 46 (1983) (per curiam) (vacating stay granted by circuit court).

12. See, e.g., Stanley v. Kemp, 105 S. Ct. 16 (1984) (denying six claims after less than two hours of consideration); Wainwright v. Adams, 104 S. Ct. 2183 (1984) (vacating stay granted by circuit court that was then considering en banc similar claim in another case); In re O'Bryan, $104 \mathrm{~S}$. Ct. 1674 (1984) (summary denial of relief); Autry v. McKaskle, 104 S. Ct. 1462 (1984) (denying

13. See Woodard v. Hutchins, 464 U.S. 377 (1984) (per curiam) (finding "abuse of the writ" and vacating stay). "There is no affirmative evidence that the claims were deliberately withheld. But... no explanation has been made as to why they were not raised until the very eve of the execution date." Id. at 379 n.2 (Powell, J., joined by four other Justices, concurring). Justices White and Stevens attacked the Court's opinion as adopting a "per se rule" against successive petitions. Id. at 383 (White \& Stevens, JJ., dissenting). See also Antone v. Dugger, 465 U.S. 200, 206 (1984) (per curiam) ("A]pplicant hardly can contend that these [successive] claims were unknown to him at [the time of the initial habeas].") (footnote omitted).

While not directly stating a new standard for successive petitions, the Supreme Court has explicitly endorsed expediting review of such petitions; the Court at the same time subtly encouraged findings of "abuse of the writ." Barefoot v. Estelle, 463 U.S. 880, 895 (1983) ("Even where it cannot be concluded that a [successive] petition should be dismissed [as an "abuse of the writ"], it would be proper for the district court to expedite consideration of the petition.").

14. See, e.g., cases cited supra note 3. In a noncapital case, Jones v. Estelle, 722 F.2d 159 (5th Cir. 1983), the Fifth Circuit articulated a virtually per se rule against successive petitions if the petitioner had "competent" counsel on an earlier habeas proceeeding, id. at 165, even if the counsel only met with the petitioner once and only raised one issue in the earlier habeas, id. at 170 (Williams, J., dissenting).

15. The writ of habeas corpus is the only practical means by which there can be federal guarantees of federal rights. The Supreme Court does not sit to correct all errors, even constitutional ones, and would be unable to review adequately the constitutional claims of all defendants, capital and noncapital, on direct certiorari review from the highest court of each state. Coleman v. Balkcom, 451 U.S. 949, 949-50 (1981) (Stevens, J., concurring in denial of certiorari). It thus falls to the federal district courts to ensure that states honor federal rights. But see Bator, Finality in Criminal Law and Federal Habeas Corpus for State Prisoners, 76 HARv. L. REv. 441 (1963) (arguing for deference to state determinations of federal rights).

16. "There is no higher duty of a court, under our constitutional system, than the careful processing and adjudication of petitions for writs of habeas corpus . . . " Harris v. Nelson, 394 U.S. 286,
292 (1968). 


\section{B. The History of Habeas Corpus and Successive Petitions}

A central theme in the history of habeas corpus is the tension between the need for finality and the desire for justice. ${ }^{17}$ This tension, dating back to Blackstone and early England, ${ }^{18}$ has become more visible as habeas corpus has been used to enforce more substantive rights. In 1867, when Congress extended the federal writ of habeas corpus to state prisoners, ${ }^{19}$ the writ could redress only a handful of rights. ${ }^{20}$ As the scope of the rights of defendants grew, ${ }^{21}$ especially during the Warren Court years, ${ }^{22}$ the frequency of habeas petitions increased. ${ }^{23}$ As the writs were increasingly used to pursue the ends of justice, the focus on finality declined. ${ }^{24}$

17. The academic debate over habeas corpus has centered not on "abuse of the writ" issues but on the central question of the validity of federal habeas relitigation of claims that have already been adjudicated in state court. Professor (now Judge) Pollak criticizes excessive concern for finality: "[W] here personal liberty is involved, a democratic society [must insist] that it is less important to reach an unshakable decision than to do justice." Pollak, Proposals to Curtail Federal Habeas Corpus for State Prisoners: Collateral Attack on the Great Writ, 66 YALE L.J. 50, 65 (1956). Professor Bator presents the leading opposing view. Bator, supra note 15 (habeas corpus should only be used to test jurisdiction of sentencing court). See also Friendly, Is Innocence Irrelevant? Collateral Attack on Criminal Judgments, 38 U. CHI. L. REv. 142 (1970) (focus of habeas review should be on innocence of petitioner, not perfection of proceedings). But see Peller, In Defense of Federal Habeas Corpus Relitigation, 16 HARv. C.R.- C.L. L. Rev. 579 (1982) (rejecting both Bator's and Friendly's approaches in favor of liberal reconsideration of all federal claims by federal habeas courts).

18. See 3 W. Blackstone, Commentaries on the Laws of England 133 (6th ed. Dublin 1775).

19. The Habeas Corpus Act of 1867 , ch. $28, \S 1,14$ Stat. $385,385-86$ (codified as amended at 28 U.S.C. $\S \S 2241-2255$ (1982)), established, for the first sime, the jurisdiction of the federal courts to review the convictions and conditions of incarceration of state prisoners. Before the act's passage, federal courts could review only the claims of federal prisoners. See, e.g., Ex parte Watkins, 28 U.S. (3 Pet.) 193, 207 (1830); In re McDonald, 16 F. Cas. 17, 21-22 (E.D. Mo. 1861) (No. 8751).

20. Originally, the writ of habeas corpus could be used to challenge only the jurisdiction of the convicting court. Ex Parte Watkins, 28 U.S. (3 Pet.) 193, 203 (1830). Professor Bator argues that the modern habeas statutes should be similarly construed. Bator, supra note 15, at 466 . But see Peller, supra note 17, at 610-16 (arguing that Bator misreads these early cases).

21. See, e.g., Johnson v. Zerbst, 304 U.S. 458 (1938) (right to counsel in all federal criminal proceedings); Waley v. Johnston, 316 U.S. 101 (1942) (prohibiting use of involuntary confessions).

22. See, e.g., Gideon v. Wainwright, 372 U.S. 335 (1963) (right to counsel in felony cases); Miranda v. Arizona, 384 U.S. 436 (1966) (right to be informed of privilege against self-incrimination); Duncan v. Louisiana, 391 U.S. 145 (1967) (right to trial by jury); In re Winship, 397 U.S. 358 (1970) (requiring proof beyond reasonable doubt of all elements of crime). For a list of rights created or "found" during the Warren years, see Greenberg, Capital Punishment as a System, 91 Yale L.J. 908, 911 n.19 (1982).

The broad scope of habeas review was clear even prior to the Warren Court's expansion of the rights of defendants. Brown v. Allen, 344 U.S. 443 (1953), suggested that all constitutional claims were cognizable under the writ of habeas corpus. The Warren Court strongly affirmed this view by rejecting the limitation of habeas to questions of jurisdiction. Fay v. Noia, 372 U.S. 391, 409 (1963); cf. Wainwright v. Sykes, 433 U.S. 72, 79 (1977) (all federal issues are "fair game on federal habeas").

23. The number of annual petitions rose from 584 in 1949 to 12,088 in 1971. Advisory Committee Note to Rule 9 of the Rules Governing \$2254 Cases [hereinafter cited as Advisory Committee Note].

24. Modern habeas has been used to redress constitutional errors many years after the original trial. See Palmer v. Ashe, 342 U.S. 134 (1951) (18 year delay in bringing habeas petition does not bar relief); see also Lloyd v. State Div. of Parole \& Probation, 557 F. Supp. 1297 (D. Md. 1983) (overturning 1967 conviction in light of 1971 Supreme Court decision); Hobbs v. Pepersack, 206 F. Supp. 
During this expansion of habeas corpus, both Congress and the Supreme Court declared that access to the writ should not be unduly restricted. In 1948, Congress amended the federal habeas corpus statutes to require that a successive petition "on a factual or other ground not [already] adjudicated" should not be denied if the judge "is satisfied that the applicant had not on the earlier application deliberately withheld the newly asserted ground or otherwise abused the writ."25 In that same year, the Supreme Court ruled in Price v. Johnston ${ }^{26}$ that successive petitions should be permitted "if for some justifiable reason [the defendant] was previously unable to assert the rights or was unaware of the significance of relevant facts."27

Fifteen years later, in the 1963 case of Sanders v. United States, ${ }^{28}$ the Court built on Price and articulated its clearest statement of the standard to be applied to successive habeas corpus petitions. The Court ruled that a federal court must reach the merits of a new claim unless the court concludes that the claim was deliberately withheld or abandoned, or unless the petitioner exhibited inexcusable neglect in failing to assert the claim earlier. ${ }^{29}$ Under Sanders, courts can dismiss successive petitions only if a defendant's "only purpose is to vex, harass, or delay." itly endorsed the Sanders guidelines in $1976 .^{31}$

The Sanders standard has proved to be workable and efficient in noncapital cases. Courts can and do summarily dismiss successive petitions raising issues that have already been adjudicated. ${ }^{32}$ Yet petitioners are still able to return to court, years after their initial convictions, and successfully raise new or unadjudicated challenges to their incarceration. ${ }^{33}$ The judicial system uses successive petitions to vindicate rights and correct er-

301 (D. Md. 1962) (overturning 1947 guilty pleas because no intelligent waiver of counsel).

25. 28 U.S.C. \$ 2244(b) (1982). The ambiguous final phrase of the amendment about "otherwise abus[ing] the writ" has provided the justification for limiting review of successive petitions. See infra
Part III.

26. 334 U.S. 266 (1948).

27. Id. at 291.

28. 373 U.S. 1 (1963). Sanders involved 28 U.S.C. \$ 2255, which grants to federal prisoners relief comparable to habeas corpus relief for state prisoners. These two post-conviction motions are treated identically in terms of successive petitions. 373 U.S. at 12-14.

29. 373 U.S. at 18 (citing Townsend v. Sain, 372 U.S. 293, 317 (1963)).

30. Id.

31. In 1976, Congress approved the Rules Governing $\S 2254$ Cases. Act of Sept. 28, 1976, Pub. L. No. 94-426, \& 1, 90 Stat. 1334, 1334. The language of Rule 9(b) explicitly reflects the Sanders standard. See Advisory Committee Note, supra note 23.

32. See, e.g., Walker v. Lockhart, 726 F.2d 1238, 1248-49 (8th Cir.), cert. denied, 104 S. Ct. 2168 (1984); United States ex rel. Townsend v. Twomey, 452 F.2d 350, 357 (7th Cir.), cert. denied, 409 U.S. 854 (1972); United States ex rel. Schnitzler v. Follette, 406 F.2d 319, 320 (2d Cir.), cert. denied, 395 U.S. 926 (1969); Cepulonis v. United States, 490 F. Supp. 381, 382-83 (E.D.N.Y. 1980); Whitney v. United States, 424 F. Supp. 1236, 1237 (E.D. Mo. 1976). 33. See Hobbs v. Pepersack, 206 F. Supp. 301 (D. Md. 1962) (granting relief on eighth federal
habeas petition). 
rors, even where the petitioner does not learn of the rights until long after conviction. ${ }^{34}$ In the area of capital punishment, the need for a mechanism to correct errors at all stages of the proceedings is especially critical, because an error can mean the taking of an innocent life. ${ }^{35}$

\section{The Unique Nature of Gapital Gases}

The death sentence and the modern campaign against it have created problems never before faced by the federal court system. ${ }^{36}$ Capital cases, as a class, are the first ever in which almost all defendants have sought to have all legal claims fully litigated in all courts. ${ }^{37}$ Volunteer attorneys ${ }^{38}$ and organizations ${ }^{39}$ have attempted to pursue every legitimate claim in every capital case. These challenges have met with unprecedented success: almost one-half of all death sentences imposed under the modern capital

34. Arguably, long lags of time before a claim is raised burden the state. Evidence may be lost or witnesses may die. The Supreme Court has already rejected this concern in noncapital cases, see supra note 24; the concern carries even less weight in capital cases. Unlike a noncapital defendant, the focus and attention of the state is never removed from the capital inmate; the state is on notice to retain evidence and preserve important testimony in preparation for the inevitable capital appeals.

35. Jack Greenberg located six cases since 1972 where death-sentenced individuals were later determined to be innocent. Greenberg, supra note 22, at 920 n.69. Since then, the Eleventh Circuit has reversed the conviction of Jack House, in whose case the evidence revealed that the victims were alive two hours after the state claimed House killed them. House v. Balkcom, 725 F.2d 608 (11th Cir. 1984). House had spent 11 years on death row pursuing his appeals.

36. The severity and finality of the death sentence calls for an especially high level of certainty in the judgment. See Woodson v. North Garolina, 428 U.S. 280, 305 (1976) ("TT) penalty of death is qualitatively different from a sentence of imprisonment, however long. . . . Because of that qualitative difference, there is a corresponding difference in the need for reliability in the determination that death is the appropriate punishment in a specific case."). The unique nature of the penalty requires that all possible steps to avoid error be taken. E.g., Beck v. Alabama, 447 U.S. 625, 642-43 (1980) (jury must be permitted to consider lesser included offense); Lockett v. Ohio, 438 U.S. 586, 604 (1978) (Burger, G.J., writing for himself and three other Justices) (all possible mitigating factors must be considered); accord Powell v. Alabama, 287 U.S. 45, 71-72 (1932) (right to counsel in capital case).

Rather than focusing on the greater need for accuracy and reliability in capital cases, this Note analyzes the unique procedural situation of a capital defendant-if the completion of the sentence is not delayed, the defendant will not be alive to pursue available remedies. This Note argues that apart from any moral requirement of perfection, this procedural peculiarity of capital cases requires that successive habeas petitions not be severely limited.

37. See Greenberg, supta note 22, at 910-14; see also M. Meltsner, Cruel and Unusual: The Supreme Court and Capital. Punishment 107-10 (1973) (describing litigation campaign); H. Bedau, The Courts, the Constitution and Capital Punishment 83 (1977). This is only a recent phenomenon. Of the over 5,000 people executed in the one hundred years before Furman $v$. Georgia, 408 U.S. 238 (1972) (per curiam), less than 500 sought any review in federal court. Greenberg, supra note 22 , at 909-10.

38. See generally Remarks by Justice Thurgood Marshall, Dedication Ceremony for the 1983 Volume of the Annual Survey of American Law, New York University School of Law (April 9, 1984) (on file with author) (describing efforts of volunteer attorneys); The Queen of Death Row, TIME, Dec. 31, 1979, at 60 (describing efforts to enlist attorneys for death-sentenced inmates).

39. The NAACP Legal Defense Fund in New York has been one of the most prominent organizations involved in litigating against the death penalty. Others include the Southern Poverty Law Center, the Southern Prisoners Defense Committee, and the Team Defense Project. Some statefinanced offices actively participate in the effort, including the Kentucky Office for Public Advocacy and the Office of Public Defenders of the State of California. 
statutes ${ }^{40}$ have been overturned, ${ }^{41}$ compared with the less than seven percent reversal rate for non-capital convictions that are appealed. ${ }^{42}$ Ironically, the success of the appeals has led to a general perception that the capital appeals process is being abused and is unduly protracted. Individual Justices on the Supreme Court have expressed this view, ${ }^{43}$ and the opinions of the Court reflect their impatience with capital appeals. ${ }^{44}$

The capital area is the only part of the criminal appeals process in which the state, rather than the defendant, is the moving force; ${ }^{45}$ laboring to carry out the sentence, the state creates the pressure to complete the appeals process. ${ }^{48}$ Some delay in the process, however, is essential in capi-

40. The "modern capital statutes" are those passed after Furman v. Georgia, 408 U.S. 238 (1972) (per curiam), which overturned almost all of the then-existing capital punishment statutes. With Furman and earlier cases, the campaign against the death penalty succeeded in having over 850 death sentences vacated. Greenberg, supra note 22, at 915. Gregg v. Georgia, 428 U.S. 153 (1976), and Woodson v. North Carolina, 428 U.S. 280 (1976), resulted in the vacation of an additional 400 death sentences. Greenberg, supra note 22, at 916 . Since Furman, 38 states have passed new capital statutes. For a list of the statutes, see W. Bowers, Legal. Homicide: Death as Punishment in AMERICA, 1864-1982, at app. B (1984).

41. NAACP Legal Defense Fund, Inc., Death Row, U.S.A. 1 (Oct. 1, 1985) [hereinafter cited as Death Row, U.S.A.]. In many of these cases, the entire conviction was overturned. Greenberg, supra note 22, at 920 \& nn.71-79 (citing cases).

42. Greenberg, supra note 22 , at $918 \mathrm{nn} .64-65$ (citing judicial reports).

43. See, e.g., Sullivan v. Wainwright, 464 U.S. 109, 112 (1983) (Burger, C.J., dissenting); Coleman v. Balkcom, 451 U.S. 949, 957-60 (1981) (Rehnquist, J., dissenting from denial of certiorari); Justice Powell Assails Delay In Carrying Out Executions, N.Y. Times, May 10, 1983, at A16, col. 1 (reporting that Justice Powell proposed in speech that Congress limit capital appeals). In Coleman, Justice Rehnquist suggested that certiorari should be promptly granted in all capital cases coming to the Supreme Court on direct appeal from the state courts. Justice Rehnquist would have the court review the merits of the claims raised, 451 U.S. at 956, thus foreclosing any later federal habeas review of those issues.

This proposal would change the institutional role of the Supreme Court by making it a court to correct every constitutional error. Given the heavy workload of the Court, the proposal would also likely lead to an even more summary review of constitutional claims than presently takes place. Justice Rehnquist seems to assume that the Court would have time to review the hundreds of new capital sentences imposed each year.

44. See, e.g., Barefoot v. Estelle, 463 U.S. 880, 895 (1983). For a full analysis of Barefoot and the Court's general impatience with capital appeals, see Note, Summary Processes and the Rule of Law: Expediting Death Penalty Cases in the Federal Courts, 95 Y ALE L.J. 349 (1985).

45. Although the state also has an administrative interest in finality and the rapid completion of the appeals process in noncapital cases, the sentences are in fact being carried out even as the habeas appeals are being litigated. Whatever the goals of the criminal law-deterrence, retribution, rehabilitation, protection of the community-they are not thwarted by the appeals process itself. Thus, it is only for administrative reasons that the states should be concerned about the duration of the noncapital appeals process. Indeed, aggressively pursuing noncapital appeals might not be the most administratively and economically efficient tactic for the state to take.

Justice Rehnquist has argued that the delay in execution required by capital appeals "not only lessen[s] the deterrent effect of the threat of capital punishment [but also] undermin[es] the integrity of the entire criminal justice system." Coleman v. Balkcom, 451 U.S. at 959 (Rehnquist, J., dissenting from denial of certiorari). Justice Stevens rejected this proposition, speculating that "the deterrent value of incarceration during [the capital appeals] period of uncertainty may well be comparable to the consequences of the ultimate step itself." Id. at 952 (Stevens, J., concurring in denial of certiorari). See also Note, Mental Suffering Under Sentence of Death: A Cruel and Unusual Punishment, 57 Iowa L. REv. 814, 826-31 (1972) (describing psychological pressure on death row inmates).

46. Capital defendants, on the other hand, gain little advantage from expediting the process. Since most capital defendants do not contest their convictions, but only their sentence, a victory on appeal 
tal cases. Unlike a prison term, a death sentence can be challenged only if it is first postponed. ${ }^{47}$ In order to protect and enforce constitutional guarantees, the ultimate execution of the sentence must be delayed so that all valid legal claims ${ }^{48}$ may be carefully presented to the courts.

Capital cases thus present a unique need for delay, a need which has led to the misconception that death-sentenced defendants intentionally withhold claims in order to delay the court proceedings. ${ }^{49}$ In responding to this perception and to the delay necessary in capital cases, the courts confront another unique aspect of capital cases: the gravity of the sentence itself. Both the special need for time to consider claims, and the severity and finality of the penalty, must be considered in crafting a rule to govern successive habeas corpus petitions in capital cases.

\section{The Procedural and Substantive Types of Successive Habeas Corpus Petitions}

In response to the lengthy habeas corpus appeals process in capital cases, the Supreme Court has fashioned an overly broad remedy. In an attempt to eliminate an arguably inappropriate use of successive petitions (to raise tactically withheld claims), the Court has also struck down appropriate uses of the writ. The Court should reevaluate its approach to successive petitions, and should devise a rule that attains the desired level of finality without sacrificing justice and fairness. To do this, the Court

usually means a life sentence. From the capital defense attorney's perspective, rushing an appeal is seldom a desirable goal. The longer the delay, the more time for new information to be discovered and for new legal arguments to develop. And, practically speaking, many capital attorneys handle more than one case at the same time. Some attorneys, especially those with capital defense organizations, see supra note 39 , seldom have time to defend against each execution crisis, much less to hurry the appeals of defendants not near execution.

47. Only in cases in which an individual is at liberty while appeals are pending is the satisfaction of a term sentence delayed. In noncapital cases, a convicted defendant may begin to serve time in prison before any appeals are heard. With a death sentence, however, a defendant obviously cannot begin to serve the sentence while still processing appeals.

This distinction between death and term sentences, in terms of delay, is most clearly seen with longterm sentences. Short sentences may run their course before an appeal can be successful. Thus, both short-term and death-sentenced individuals must delay their sentences to fight them. The irreversibility of the death sentence sets it apart, however, and demands that the sentence be delayed even where a short-term sentence would not be.

48. There might be incentives to present invalid claims if no valid claim exists to be asserted. Under the proposal suggested by this Note, a judge would have the power to dispose quickly of claims that, on their face, clearly lack merit.

49. Justice Brennan has criticized this fear of intentional delay. "[N]o rational lawyer would risk the 'sandbagging' feared by the Court." Wainwright v. Sykes, 433 U.S. 72, 103 (1977) (Brennan, J., dissenting). If the lawyer does this, and "loses on this gamble, all federal review would be barred, and his 'sandbagging' would have resulted in nothing but the forfeiture of all judicial review of his client's claims. The Court, without substantiation, apparently believes that a meaningful number of lawyers [would do this]. I do not. That belief simply offends common sense." Id. at $104 \mathrm{n} .5$ (discussing procedural default rules of Sykes). 
must distinguish the different procedural postures of successive petitions, and must analyze the different types of claims raised in the petitions.

\section{A. Procedurally Forced Successive Petitions and an Appropriate Response}

\section{The Problem}

The finality of the death sentence, combined with state and federal procedural rules, sometimes forces the use of successive habeas corpus petitions. In some capital cases, a peculiar situation arises in which the state courts refuse to stay an execution date and the defendant is forced to request a stay from the federal courts by filing a petition for habeas corpus, even if federal procedural rules prevent the defendant from bringing all valid claims into federal court in the first habeas petition. In this situation, the defendant is faced with the choice of not requesting a stay (and thus being executed) or requesting a stay based on some, but not all, of the claims raised in state court (and thus having either to forgo the remaining claims or to raise them in a successive petition).

The interaction between state and federal courts creates these situations in which certain issues become ripe for federal review before others. The doctrine of exhaustion ${ }^{50}$ requires that all claims presented in a federal habeas petition be first presented, and ruled upon, in the state courts. If the state courts do not complete review of all claims simultaneously, a defendant is left with some issues ready for federal review while other claims remain bottled up in the state courts. ${ }^{51}$

50. Under 28 U.S.C. $\$ 2254$ (b), habeas corpus relief "shall not be granted unless it appears that the applicant has exhausted the remedies available in the courts of the State . . ." See also 28 U.S.C. $\S 2254$ (c) (no exhaustion until applicant has no possible state procedure in which to raise claim).

Rose v. Lundy, 455 U.S. 509 (1982), held that a district court should dismiss without prejudice "mixed petitions," which contain both exhausted and unexhausted claims. This ruling stemmed from holdings of the Fifth and Ninth Circuits. Id. at 513 n.5 (citing Galtieri v. Wainwright, 582 F.2d 348 (5th Cir. 1978) (en banc); Gonzales v. Stone, 546 F.2d 807 (9th Cir. 1976)). Those two circuits, however, stated that in the case of a mixed petition, the inmate would be permitted to bring a second petition raising the previously unexhausted issues. Galtieri, 582 F.2d at 355, 358-59, Gonzales, 546 F.2d at 810 . Four members of the Rose Court, however, rejected that view. 455 U.S. at 521 (O'Connor, J., writing for herself and three other Justices) ("a prisoner who decides to proceed with his exhausted claims and deliberately sets aside his unexhausted claims risks dismissal of subsequent
federal petitions").

51. A hypothetical illustrates this timing problem: A trial court convicts a defendant and sentences him to death. The court-appointed attorney handles the direct appeal to the state supreme court, raising Issue "A." The state supreme court denies relief. The court-appointed attorney then ceases to work on the case. (An indigent defendant has a constitutional right to counsel only at trial and in an appeal of right. Compare Ross v. Moffitt, 417 U.S. 600 (1974) (no right to counsel for discretionary review) with Gideon v. Wainwright, 372 U.S. 335 (1963) (right to counsel in criminal trial) and Douglas v. California, 372 U.S. 353 (1963) (right to counsel for appeal of right in criminal case).) A volunteer attorney, experienced in capital cases, begins work on post-conviction appeals, and discovers 
When this occurs in states like Florida, which does not commonly grant stays of execution during post-conviction proceedings, ${ }^{\mathbf{5 2}}$ the defendant may be forced to rely on a successive petition. ${ }^{\text {ss }}$ Once the state courts have completed their review on direct appeal from the conviction, the stay of execution issued by the state court expires, even though state postconviction appeals may still be pending. The defendant then has no choice but to go to federal court for a stay, whether or not all possible claims are ripe for federal review. When later claims become ready for review, the defendant must resort to a successive petition or forgo raising the claims in federal court. ${ }^{54}$

Under the federal courts' new approach to successive petitions, those issues still before state courts at the time of the initial federal habeas petition are later treated summarily. Any non-capital defendant has the op-

a new claim, Issue " $B$." Under the state rules, Issue " $A$ " cannot be brought in a post-conviction appeal because the high court has already ruled against the claim. Due to the requirement of exhaustion, however, the defendant must bring Issue " $\mathrm{B}$ " in a state post-conviction proceeding before he presents the issue to the federal court. If, as happens in some states, stays of execution are seldom issued during the state post-conviction appeals, the defendant is forced to raise Issue " $\mathrm{A}$ " in federal court to forestall an execution, even though the defendant cannot yet bring Issue " $B$ " to the federal court. The defendant must therefore resort to a successive habeas petition or lose the opportunity to raise Issue " $B$ " in federal court. Under the federal courts' new approach to successive petitions, especially as articulated in Jones v. Estelle, 722 F.2d 159, 165 (5th Cir. 1983), any issues raised on successive petition in this situation would be summarily dismissed.

52. In the over 100 cases in which death warrants have been signed in Florida, the Florida courts have stayed less than 20 executions. In the other cases, the defendants have been forced to request stays from the federal courts. This problem, also present in Texas, arises at least in part because state post-conviction proceedings in Florida are held in the sentencing court, usually in front of the sentencing judge. (This procedure differs from that in Georgia, for instance, where the court in the county of incarceration hears the state habeas petition.) Thus, in Florida, the defendant must ask the original trial judge to stay her own judgment and to find the original proceedings faulty. According to one Florida attorney who handles death cases, stays are generally awarded by the state courts only when the original judge has died and a new judge reviews the case. Telephone interview with Richard Burr,
Office of the Public Defender, West Palm Beach, Fla. (May 13, 1985).

53. The problem is most serious for inmates who are unable to obtain appellate counsel early in the appeals process. When the state sets an execution date, the inmate must hurriedly find an attorney, who then has only a matter of days to obtain a stay of execution. If the state court does not issue a stay, the attorney must go to federal court without having had time to research the entire case, much less to litigate ail possible issues in state court. See Antone v. Dugger, 465 U.S. 200, 205-06 nn.3-4 (1984) (per curiam) (denying stay even though Antone's trial counsel dropped Antone's case days before his scheduled execution and replacement counsel omitted critical issues from initial habeas petition); $c f$. Shaw v. Martin, 613 F.2d 487, 492 n.2 (Phillips, Circuit Judge 1980) ("It is completely unrealistic to suppose a practical ability to exhaust normal avenues of post-conviction review provided by both state and federal law within [a four-week] time frame, even were every step to be taken within the shortest conceivable time by both litigants and courts.").

54. This situation requires the petitioner to forgo one constitutional right to assert another. The Supreme Court has frequently rejected this choice. See, e.g., Brooks v. Tennessee, 406 U.S. 605 (1972) (rule requiring defendant to testify first or not at all deprived defendant of right to counsel and infringed on right to remain silent); Gardner v. Broderick, 392 U.S. 273 (1968) (impermissible to force choice between remaining silent and retaining job as policeman).

This situation is even more extreme than the case of Fay v. Noia, 372 U.S. 391, 438-40 (1963), which declared that waivers made to lessen the risk of capital punishment are not sufficiently voluntary to require a federal habeas court to abstain from review. Here, the petitioner involuntarily loses constitutional claims in order to avoid an imminent execution. 
tion to wait until crucial second claims catch up before entering federal court. $^{\text {SB }}$ The capital defendant, however, cannot afford to wait; he is forced into federal court early to avoid execution.

\section{A Proposed Response}

These cases are not true successive claims. Rather, the defendant is diligently attempting to bring all valid claims through the state court system and into the federal system within the same general time frame. Prior to the initial federal proceedings, the potentially successive claims have already been raised, but not adjudicated, in state court. If federal courts summarily reject successive petitions on these later claims, they are allowing state procedural rules to deny the vindication of federal constitutional rights in federal courts. Whether or not this bottling up is a willful attempt to thwart federal review, an individual state's procedure should not be able to restrict the right to federal habeas corpus.

A better approach to the problem of procedurally forced successive petitions would be for federal district courts to issue a stay of execution on the initial petition for habeas relief, but to hold the case in abeyance until all issues are exhausted in state courts and therefore ready for federal review. Although only a few lower federal courts have ever held a petition in abeyance (and then only in specifically limited circumstances), ${ }^{56}$ the Supreme Court itself in Sanders encouraged "imaginative handling of a prisoner's first motion" in order to "anticipate and avoid the problem of a hearing on a second or successive motion."57

55. Not all noncapital defendants will wait in these situations. Some might decide that the issue(s) ready for federal review are so strong that there is no need to wait until others catch up. This, however, is a tactical judgment; no pressure to avoid execution forces it.

56. In Arango v. Wainwright, 716 F.2d 1353 (11th Cir. 1983), the Eleventh Circuit ordered the district court to hold a petition in abeyance; in denying the state's petition for rehearing, however, the court emphasized that a state court stay of execution was already in effect. 739 F.2d 529 (11th Cir. 1984). The court did not seem willing to adopt the proposal presented here: to hold a petition in abeyance (and issue a federal stay), whether or not a state court stay remained in effect.

In Shaw v. Martin, 613 F.2d 487 (Phillips, Circuit Judge 1980), Judge Phillips granted a stay where the petitioner had appeals pending in three courts: a petition for rehearing of denial of certiorari in the U.S. Supreme Court, an appeal in the court of appeals from the denial by the district court of an initial federal habeas petition, and a state post-conviction proceeding. The order instructed the district court to wait until the state post-conviction appeals were adjudicated, allowing the issues raised in them to be presented in federal court. Id. at 493. Judge Phillips offered "to dissolve this stay order if . . . the Supreme Court of South Carolina should resolve itself to stay the execution pending exhaustion of [state] post-conviction review procedures." Id. Eighteen months later, the Fourth Circuit granted a writ of mandamus directing the district court not to entertain an application for vacation of the earlier stay. In re Shaw, No. 81-1396 (4th Cir. May 15, 1981). The Fourth Circuit reviewed the merits of the claims only after all of the petitioner's issues were consolidated in one habeas appeal. See Shaw v. Martin, 733 F.2d 304, 308 (4th Cir. 1984).

57. 373 U.S. 1, 22 (1963). In Sanders, which involved a prisoner's pro se habeas petition, the Court suggested that the lower court could have attempted to locate and rule on any valid claim the prisoner could bring. This logic suggests that a federal court should hold an initial habeas petition in abeyance when the prisoner has already brought other claims into state court. 
This approach will allow for a careful review of all of the issues presented, without forcing defendants to waive or default on the claims that are slow to emerge from state courts. The enforcement of federal rights will thus not depend on the procedures and calendars of state courts. $^{68}$

\section{B. True Successive Petitions and the Appropriate Standard of Review}

In true successive petition situations, and even in some cases where an initial petition is held in abeyance, ${ }^{59}$ the federal courts will be forced to evaluate the justifications for delayed habeas petitions. To create a more just approach to successive petitions, it is necessary to analyze each of the situations in which such petitions arise. There are seven general categories of claims raised in successive petitions. ${ }^{80}$ These categories, reviewed below, raise different considerations in terms of fairness and delay, and should not be grouped together under one rule against successive petitions.

Rose v. Lundy, 455 U.S. 509 (1982), which requires courts to dismiss without prejudice "mixed petitions" that include unexhausted claims, does not prohibit a district court from holding a habeas petition in abeyance. As the exhaustion requirement is not a jurisdictional constraint, see Sharpe v. Buchanan, 317 U.S. 238 (1942), Rose requires only that relief not be granted on mixed petitions (until they are no longer mixed). Rose intended to avoid the judicial inefficiency of piecemeal litigation. 455 U.S. at 520. The hold-in-abeyance proposal is the most efficient option, avoiding both piecemeal litigation and successive petitions. By allowing district courts to avoid the hearing on the "abuse of the writ" question, see Price v. Johnston, 334 U.S. 266, 292 (1948), the hold-in-abeyance proposal would enable the courts to review most capital cases in one and only one hearing.

58. The federal courts' general deference to state procedural requirements is a matter of judicial discretion based on federalism principles. Wainwright v. Sykes, 433 U.S. 72, 84, 88 (1977). A court can and should put this deference aside when justice requires. In the case of a successive habeas petition, a court should not hesitate to issue a stay when the state courts refuse to do so; the stay does not short-circuit any state court proceeding.

The idea of a federal court stepping in when a state court does not act is not new. At least one lower court has decided that it should provide, in the context of a federal habeas proceeding, the postconviction procedure that the state court should have provided. Grigsby v. Mabry, 637 F.2d 525, 528-29 (8th Cir. 1980) (no "special circumstances" indicated that state court was more appropriate forum). Other courts have given states the choice of providing the required procedure or releasing the defendant. See, e.g., Hart v. Eyman, 458 F.2d 334, 339-40 (9th Cir.), cert. denied, 407 U.S. 916 (1972); Buchanan v. United States ex rel Reis, 379 F.2d 612 (5th Cir. 1967) (per curiam).

59. The hold-in-abeyance proposal does not eliminate all potential for abuse. A federal court, for instance, might hold a petition raising Issue " $A$ " in abeyance, waiting for Issue " $B$ " to be adjudicated in state court. If, when Issue " $B$ " is almost ripe for federal review, the petition raises Issue " $C$ " in state court, the federal court must decide whether to continue holding the petition in abeyance or to proceed to consider the first two issues. In either case, the court must evaluate the reasons for the delay.

60. The categorizations used here necessarily raise the question of which party has the burden to show that a claim is in a given category. At the outset, the state has the burden to plead an abuse of the writ. Sanders v. United States, 373 U.S. at 10-11; Price v. Johnston, 334 U.S. at 292. After the state has alleged an abuse of the writ, Rule 2 of the Rules Governing $\$ 2254$ Cases and the Model Form for Use in 28 U.S.C. $\$ 2254$ Cases Involving a Rule 9 Issue require the habeas petitioner to establish, in a successive petition, why there is no abuse. Because the habeas proceeding is essentially "civil" in nature, see Browder v. Director, Dep't of Corrections, 434 U.S. 257, 269 (1978), the burden of proof is "the usual "preponderance of the evidence' standard," Sumner v. Mata, 449 U.S. 539, 551 (1981). 


\section{Types of Successive Claims}

\section{a. Frivolous Claims}

The type of claim raised in successive petitions that is perhaps the easiest to deal with is the clearly frivolous claim. ${ }^{61}$ A claim is frivolous if on its face it has no legal merit, even if the alleged facts on which the claim is based are assumed to be true. Under any plausible approach, including the Sanders formula and the federal courts' new approach to successive petitions, such claims should be summarily denied. ${ }^{62}$

\section{b. Relitigated Claims}

As with frivolous claims, claims already litigated in federal court should be summarily dismissed. ${ }^{63}$ Although res judicata does not apply to habeas corpus petitions, ${ }^{64}$ the federal courts should not be required to give a full evidentiary hearing to claims that have been carefully reviewed and adjudicated in an earlier federal habeas proceeding. Assuming that the claim is truly the same as one previously litigated (i.e., no new facts or law bear on the claim), the claim need be reviewed only in exceptional circumstances, such as when a judge made a clearly erroneous ruling on the first habeas petition or when the attorney on the initial claim was ineffective. ${ }^{65}$

61. Many claims ultimately deemed frivolous are likely to arise in pro se petitions.

62. In deciding whether a habeas petition is frivolous, the court should assume the facts presented to be true, an approach similar to that taken with motions to dismiss for failure to state a claim made under FED. R. Crv. P. 12(b)(6). If, assuming the facts, no relief is warranted, the petition should be quickly dismissed. But if the facts might lead to relief, the claim falls into one of the other categories in this Section.

63. The term "relitigated claims" refers to claims that have already been litigated in the federal system. This Note adopts the widely held assumption that federal courts may reconsider federal claims on which state courts have already ruled. Thus, this Note does not use the term "relitigate" in the same manner as the articles which challenge or defend that assumption. See, e.g., Bator, supra note 15; Peller, supra note 17.

Further, a claim is not considered to have been litigated in federal court if the only federal action taken on it has been a Supreme Court denial of certiorari to the highest court of the state. Federal courts have frequently granted relief on federal claims that the Supreme Court chose not to reach on appeal from the state court. See, e.g., Estelle v. Smith, 451 U.S. 454, 460 (1981) (noting earlier denial of certiorari); Sheppard v. Maxwell, 384 U.S. 333, 335 n.1 (1966) (same).

64. See Sanders v. United States, 373 U.S. at 8 ("Conventional notions of finality of litigation have no place where life or liberty is at stake and infringement of constitutional rights is alleged. . . The inapplicability of res judicata to habeas .... is inherent in the very role and function of the writ."). But see Kelley, Finality and Habeas Corpus: Is the Rule that Res Judicata May Not Apply to Habeas Corpus or Motion to Vacate Still Viable?, 78 W. VA. L. REv. 1 (1975). Kelley argues that res judicata should apply to habeas, but then proceeds to recognize enough exceptions so as to exclude only overlooked, abandoned, and tactically withheld claims. Id. at $53 \mathrm{n.290}$.

65. These exceptions might better be viewed as new claims arising not out of the original arrest, trial, or sentencing, but out of the first habeas proceeding itself. There must, of course, be a limit on how many times a defendant can claim ineffective assistance of appellate counsel. At a minimum, however, capital defendants should not be penalized for the inexperience or lack of resources of counsel hurriedly retained in the face of an impending execution. Contra Antone v. Dugger, 465 U.S. 200, 205-06 (1984) (per curiam) (denying stay of execution). 
The Sanders decision, while permitting judges to deny relitigated claims quickly, does not categorically reject all such claims. Rather, it entertains the possibility that a claim can be relitigated "[e]ven if the same ground was rejected on the merits on a prior application," but places the burden on the applicant "to show that the ends of justice would be served by permitting the redetermination of the ground."

The Supreme Court's new summary approach to successive petitions does not appear to include an "ends of justice" test for relitigated claims. ${ }^{67}$ Arguably, with claims of this type, concern for finality will almost always outweigh concern for justice; unless the initial proceeding was somehow flawed, questions of justice should have been resolved with the first habeas petition. In the area of capital punishment, however, the "ends of justice" possibility for reconsideration of a claim is an important safeguard against mistake in the imposition of a death sentence.

\section{c. "New Law" Claims}

Claims based on "new law," if the new law has been deemed to apply retroactively, clearly should be reviewed on the merits even if raised in a second habeas corpus petition. The Supreme Court's new approach, however, steps back from the Sanders formula and puts "new law" claims in jeopardy of summary dismissal.

"New law" claims are usually made after the Supreme Court finds a new constitutional right or strengthens an old one. ${ }^{68}$ With almost all expansions of the rights of criminal defendants, the Supreme Court must decide whether the change retroactively reaches defendants already arrested or convicted at the time of the change. Frequently, however, the Court delays deciding the issue of retroactivity until it is squarely presented. ${ }^{68}$

66. 373 U.S. at 16.

67. In a related area of habeas corpus law, the Wainwright $v$. Sykes procedural default test includes a proviso that the federal courts should reach an otherwise barred claim if the defendant will "in the absence of such an adjudication . . . be the victim of a miscarriage of justice." 433 U.S. 72, 91 (1977).

68. Cases such as Gideon v. Wainwright, 372 U.S. 335 (1963) (right to counsel in felony cases), and Miranda v. Arizona, 384 U.S. 436 (1966) (right to be informed of privilege against selfincrimination), are examples of opinions making "new law." "New law," however, can emanate from places other than the Supreme Court. State courts can create new state law by interpreting their state constitutions; this type of "new law" claim is most appropriately raised in state court. See, e.g., Rose v. Hodges, 423 U.S. 19 (1975).

Congress can also create new law by altering some statutory aspect of the criminal justice system. Statutory claims are cognizable in federal habeas proceedings in certain situations. See, e.g., Davis v. United States, 417 U.S. 333, 344-46 (1974). An example of a statute that gives state inmates a federal cause of action is Title III of the Omnibus Crime Control and Safe Streets Act, 18 U.S.C. $\S \S$ 2510-2520 (1982) (limiting wiretapping by law enforcement agencies).

69. See, e.g., Desist v. United States, 394 U.S. 244, 254 (1969) (refusing to give retroactive effect to Katz v. United States, 389 U.S. 347 (1967), which extended Fourth Amendment rights); Johnson 
If a newly announced constitutional right is given only prospective effect, then successive petitions attempting to claim the right retroactively should be summarily dismissed. If, however, the "new law" is retroactive, a defendant should be able to take advantage of it, even if he filed his initial habeas petition prior to the change in the law. Similarly, if the Court has reserved its decision on retroactivity, a defendant deserves an opportunity to litigate that question. ${ }^{70}$ To deny retroactive "new law" claims in successive petitions creates the irrational situation of having retroactivity depend on whether a defendant has already filed a first habeas corpus petition at the time of the change in the law. ${ }^{71}$ This, however, is exactly the possibility created by the federal courts' new approach to successive petitions.

\section{d. "New Fact" Claims}

Just as courts should fully review successive petitions based on "new law," they should also fully review successive petitions based on "new facts." The category of "new facts" includes any evidence discovered after the initial trial that might either affect the outcome of a new trial or indicate that the defendant's constitutional rights were violated in the earlier proceeding. Because " $[t]$ he primary purpose of a habeas corpus proceeding is to make certain that a man is not unjustly imprisoned,"72 claims based on newly discovered evidence, such as a confession by another individual or proof of prosecutorial misconduct, are among the situations most appropriate for habeas corpus relief. No defendant, capital or otherwise, should be barred from presenting new evidence that casts doubt on the validity of a conviction.

In addition, capital cases present a far more subtle type of "new" evidence: evidence which should have been introduced in mitigation during the sentencing phase of a capital trial. ${ }^{73}$ Because any favorable evidence

v. New Jersey, 384 U.S. 719, 732 (1966) (giving only partial retroactive effect to Miranda).

70. Cf., e.g., Autry v. Estelle, 464 U.S. 1301 (White, Circuit Justice 1983) (staying execution pending final disposition of case with related issue).

71. A defendant who raised an issue prior to a favorable change in the law would be penalized relative to a defendant who raised the issue later. Such a rule would create an incentive to delay filing initial habeas corpus petitions-exactly the opposite of the incentive currently desired by the Supreme Court. Federal guarantees of constitutional rights should not depend on when a defendant, relative to others, raises the claim. See Fay v. Noia, 372 U.S. 391, 441 (1963) ("IS]urely no just and humane legal system can tolerate a result whereby a Caminito and a Bonino are at liberty because their confessions were found to have been coerced yet a Noia, whose confession was also coerced, remains in jail for life [because he delayed raising the claim].").

72. Price v. Johnston, 334 U.S. 266, 291 (1948).

73. In the wake of Furman v. Georgia, 408 U.S. 238 (1972) (per curiam), most new capital statutes have established a bifurcated proceeding in which guilt or innocence is decided in a separate stage from the sentencing decision. At the sentencing phase, any mitigating evidence can be introduced to discourage the finding or recommendation of a death sentence. 
can be presented in the sentencing hearing in mitigation of the offense, and because many of the attorneys who handle capital cases at the trial and initial appellate levels are inexperienced in death penalty proceedings, ${ }^{74}$ expert appellate attorneys in capital cases can and frequently do find evidence that should have been introduced to dissuade the jury from imposing death. ${ }^{75}$

This type of evidence, uncovered long after the trial, raises serious questions about the level of diligence due a capital defendant by trial counsel. In light of the severity of the sentence, capital defendants should not be penalized for a lack of awareness or willingness on the part of trial counsel to investigate the defendant's case fully. ${ }^{78}$

Thus, whether the "new facts" concern the validity of either the conviction or the sentence, the defendant should be allowed to raise the new claims in a successive habeas corpus petition. ${ }^{77}$ This opportunity is foreclosed if successive petitions continue to be summarily dismissed.

\section{e. Overlooked and Unresearched Claims}

For a variety of reasons-lack of experience, time, or money-some capital defendants' initial appellate counsel overlook or are unable to research all valid constitutional claims arising from the capital trial. ${ }^{78}$ When the failure to present claims in an initial petition does not stem from a tactical decision to withhold claims, but from limited resources, the failure is not the type of intentional abuse of the habeas process that a policy regarding successive petitions should attempt to prevent. In a system that seldom provides funds for appellate counsel ${ }^{79}$ and in which the courts ex-

74. Court-appointed attorneys, especially in smaller towns, seldom have any experience in defending a capital case. The additional procedure in a capital trial requires insight and effort beyond that needed in most noncapital cases.

75. See, e.g., Clark, supra note 1, at 402 (evidence of family tragedy not introduced in penalty phase of trial).

76. If this "new" evidence was in fact known to trial counsel and intentionally withheld, equally serious ineffectiveness problems arise. It might be argued that upholding ineffectiveness claims in this situation would encourage attorneys to be intentionally ineffective in order to preserve that issue for appeal. Yet, especially in light of the near impossibility of establishing a claim of ineffective assistance of counsel on appeal, it is almost inconceivable that an attorney would withhold evidence that might prevent the imposition of the death penalty at the initial trial.

Only in a situation where the verdict of death is virtually a foregone conclusion, see, e.g., Coleman v. Balkcom, 451 U.S. 949, 953 (1981) (Marshall, J., dissenting) (jurors admitted influence of pretrial publicity), can one imagine that an attorney would intentionally be ineffective. In such cases, however, the very fact that the verdict is foregone raises doubts about the validity of the verdict.

77. Under the preponderance of the evidence standard applicable in habeas corpus cases, see supra note 60 , the petitioner bears the burden of establishing a "new fact." At the outset of the successive petition proceeding, however, the district court should assume the new facts to be true in determining whether or not there is a potentially valid "new fact" claim presented.

78. See Clark, supra note 1, at 401; Rising Death Row Population Burdens Volunteer Lawyers, N.Y. Times, Aug. 23, 1982, at A15, col. 5.

79. Most states provide appointed counsel only as far as constitutionally required (the appeal of 
pedite capital appeals, ${ }^{80}$ a capital defendant should not be responsible for the failure of counsel to raise an issue due to lack of resources or time. ${ }^{81}$

By focusing on the "deliberate[ness]" of the withholding of claims and the intention to "vex, harass, or delay," judge to reach claims appellate counsel failed to raise at an earlier stage because of ineptness, poverty, or an impending execution date. By viewing overlooked claims as tactically withheld, and thus summarily denying successive petitions with little or no consideration of the merits of the claims, the Supreme Court is foreclosing this option.

\section{f. Abandoned Claims}

Claims that were raised in early state proceedings but were not later presented in an initial federal habeas corpus petition can actually be classified in one of the other categories presented in this Section. If the abandonment of a claim was a strategic decision made by counsel, it falls into the category of tactically withheld claims. If, however, the decision to abandon the claim was not motivated by an attempt to gain advantage, the claim comes under the overlooked or unresearched claim category; either the attorney simply incompetently overlooked the claim, or the attorney did not pursue it for more practical, perhaps financial, reasons. In either case, the claims should be treated as overlooked or unresearched claims; an appropriate standard for successive petitions should not prevent consideration of these claims on their merits.

\section{g. Tactically Withheld Claims}

The most troubling category consists of claims that the initial appellate attorney tactically withheld, either intending to raise them in a later proceeding or deciding that the client would be better off if they were not raised at all. These withheld claims, viewed as an attempt to manipulate

right to the state's highest court). See Ross v. Moffitt, 417 U.S. 600 (1974) (states not compelled to provide counsel to indigents seeking discretionary Supreme Court review of convictions). A few states do provide some assistance in post-conviction proceedings. Greenberg, supra note 22 , at 912 n.24 (citing the Office for Public Advocacy in Frankfort, Kentucky, and the California Office of Public Defenders). Only California explicitly allows for appointment of counsel to prepare Supreme Court certiorari petitions. See In re Anderson, 69 Cal. 2d 613, 633, 447 P.2d 117, 131, 73 Cal. Rptr. 21, 35 (1968), cert. denied, 406 U.S. 971 (1972).

80. See generally Note, supra note 44 (describing acceleration of appeals process).

81. The Constitution requires, at the very least, that the defendant have counsel consider and be able to afford to research all possible claims. Most courts view the question of which issues to raise on appeal as a decision to be made by counsel (unlike, for instance, the decision to plead guilty). See Jones v. Barnes, 463 U.S. 745 (1983) (no constitutional right to have appellate counsel raise every non-frivolous issue that criminal defendant requests).

82. 373 U.S. at 18. 
the judiciary and abuse the writ of habeas corpus, most concern the courts. $^{83}$

But it is in this category of successive claims that the greatest injustice is done to some defendants. Many capital defendants, some sentenced over ten years ago, filed their first federal habeas petition years before the Supreme Court altered its approach to successive petitions. Although few, if any, cases have been documented, some attorneys may have decided that "abusing" the system was in the best interest of their clients, and thus may have decided to withhold claims. Because the courts were at that time lenient toward successive petitions, a decision to withhold claims may have then been a sound tactical judgment. ${ }^{84}$

Now these defendants find that the rules have changed. When, years after initial filing, their first habeas petitions fail, their other valid claims cannot be brought into court. The irony of this situation is revealed when viewed alongside the "new law" claims discussed above. ${ }^{85}$ The restrictive approach of the Supreme Court toward successive petitions limits the ability of defendants to take advantage of "new [positive] law," yet at the same time imposes "new [negative] law" in the form of these very restrictions on successive habeas corpus petitions. A just rule, such as the Sanders "ends of justice" approach, would not allow so unfair a result.

\section{The Sanders Formula Revitalized}

This analysis of the various types of claims commonly raised in successive habeas corpus petitions leads to the conclusion that the new approach

83. There are at least three situations in which an attorney might knowingly withhold a potentially valid claim from an initial habeas corpus petition, but want to raise it later:

First, the attorney decides that the claims actually presented are so meritorious that there is no need to present other potential issues. If the attorney is correct that the presented claims are winning claims, then there is no successive petition problem. If, however, the attorney is wrong, serious questions about the effectiveness of the assistance of appellate counsel arise.

Second, the attorney is aware of the claim but does not have the time and/or resources to pursue the claim. See supra note 78 . No matter how competent by traditional standards the attorney may be, this situation also raises the question of effectiveness of counsel.

Third, the attorney decides that there is a tactical advantage in withholding the claim. While this is the hardest case, this Note suggests that even this attorney may be constitutionally ineffective.

There are no common sanctions, such as bar disciplinary proceedings, against an attorney for intentionally withholding claims from a habeas petition. Thus, the primary deterrent to the attorney is the harm to the client that will likely follow from a lost, valid claim. In the context of a capital case, that harm is devastating, and likely to be a serious deterrent to the withholding of claims.

At least one leading capital defense organization strongly discourages witheld claims: "Each [habeas] petition ... must be litigated by counsel as if there will be no second chance to raise an issue, to develop the facts more fully, or to explore the legal arguments more thoroughly or creatively." J. Liebman, Federal Habeas Corpus Manual for Capital Cases 16 (NAACP Legal Defense Fund, Tent. Draft 1983) (on file with author).

84. In the past, the Sanders formula has not been rigorously applied. Now that the Supreme Court has indicated its seriousness about restricting successive petitions, no rational lawyer could think this a sound approach. Wainwright v. Sykes, 433 U.S. 72, 103 (1977) (Brennan, J., dissenting).

85. See supra text accompanying notes 68-71. 


\section{The Rush to Execution}

adopted by the federal courts must be reevaluated and the Sanders rule revitalized. A fair successive petition rule should permit "new law," "new fact," overlooked, and unresearched claims. ${ }^{88}$ On the other hand, it should limit frivolous, relitigated, and tactically withheld claims. In limiting these claims, however, the rule cannot be so strict as to prevent the consideration of claims in the interest of justice, even if the claims were intentionally withheld or have been previously adjudicated.

Just such a rule is embodied in the Sanders formula. Although the case has never been overruled, its guidelines have fallen into disuse. Those guidelines are in keeping with the historical, statutory, and legal spirit of habeas corpus, which should be widely available to enforce constitutional guarantees.

The Sanders formula will permit courts to control delay without inhibiting justice. The need to ensure that valid claims are addressed and that justice is not limited is strong in all criminal cases; it is strongest in capital cases. If the states choose to impose the "ultimate sanction," the Constitution requires that it be imposed with care and certainty. The federal courts should not rush this determination.

86. A case currently awaiting decision from the Eleventh Circuit sitting en banc directly confronts the successive petition problem in a situation where the claims have strong merit and the explanations for delay are legitimate. Moore v. Zant, 734 F.2d 585 (denying relief), vacated for rehearing en banc, id. at 604 (11th Cir. 1984). Moore raised a variety of claims in his successive petition: 1) an ineffective assistance of trial counsel claim, which his first appellate counsel refused to raise because he was too busy, which Moore tried to raise pro se directly to the initial habeas court, and which the initial habeas court refused to hear; 2) a "new law" claim concerning the right to remain silent in interviews to be used in a capital sentencing hearing, based on Estelle v. Smith, 451 U.S. 454 (1981), decided months after the denial of Moore's inital habeas; 3) a "new law" claim concerning the right to cross-examine hearsay witnesses whose statements appear in the state's presentence report, based on Proffit v. Wainwright, 685 F.2d 1227, 1254-55 (11th Cir. 1982), modified, 706 F.2d 311 (1983), cert. denied, 464 U.S. 1002 (1983), decided years after the denial of Moore's initial habeas; and 4) "new fact" claims of racial discrimination in capital sentencing based on studies not concluded until after the denial of the initial habeas. En Banc Brief for Petitioner-Appellant at 9-11, Moore v. Zant, No. 84-8423 (11th Cir. argued Sept. 11, 1984). Despite these and other claims (including a claim of ineffective assistance of appellate counsel), the strength of which the district court acknowledged, the district court denied the successive petition as an abuse of the writ. A three-judge panel of the Eleventh Circuit later adopted and reprinted the unpublished district court order. Moore v. Zant, 734 F.2d at 587 (1984). In dissenting from the panel opinion, Judge Kravitch wrote:

Unquestionably, genuine abuses of the writ must be prevented, but we must not adopt measures so broad that legitimate claims will not be heard. I fear that the majority's approach today loses sight of the fact that the [abuse of the writ] doctrine "is not intended to automatically foreclose each petitioner who fails to claim every ground for relief in his first application in federal court."

Id. at 604 (Kravitch, J., dissenting) (quoting Haley v. Estelle, 632 F.2d 1273, 1276 (5th Cir. 1980)). 